\title{
Sex Identification of in vitro Plants of Carica papaya L. MSXJ Hybrid through Molecular Markers
}

\author{
Nieto-Soriano M. ${ }^{1}$, Galindo-Tovar M. E. ${ }^{1}$, Pastelín-Solano M. C. ${ }^{2}$, Solano-Rodríguez L. A. ${ }^{3}$, Leyva-Ovalle O. R. ${ }^{1}$ \\ Cruz-Cruz Carlos Alberto ${ }^{1}$ y Castañeda-Castro O. ${ }^{2^{*}}$
}

\begin{abstract}
${ }^{1}$ Universidad Veracruzana, Facultad de Ciencias Biológicas y Agropecuarias, Amatlán de los Reyes Veracruz, Veracruz. ${ }^{2}$ Universidad Veracruzana Facultad de Ciencias Químicas, Orizaba, Veracruz, México. ${ }^{3}$ Producción Genética Agropecuaria de México (PROGAMEX), Córdoba, Veracruz, México

*Corresponding author: odcastaneda@uv.mx
\end{abstract}

\begin{abstract}
Objective: To identify the sex of in vitro plants of papaya (Carica papaya L.) MSXJ hybrid obtained via somatic organogenesis, through SCAR type molecular markers.

Design/Methodology/Approach: Eight-month old MSXJ papaya hybrid plants in the fructification stage were collected in Cotaxtla, Veracruz, Mexico. They were superficially disinfected with abundant running water, detergent during 30 min, and then alcohol at 70\% was added for one minute, commercial chlorine at 30\% for 30 min, and they were rinsed with sterile distilled water; then the meristems were cultivated in MS medium and after $30 \mathrm{~d}$ a subculture was made. The DNA extraction was made with the CTAB method, and the DNA PCR was done with the Deputy et al. (2002) method, and the primers T1, T12 and W11 were used.
\end{abstract}

Results: The T1 primer was the positive control and the T12 and W11 primers allowed the amplification of fragments that identify hermaphrodite, feminine and male plants, while the T12 and W11 primers were specific for hermaphrodite plants. Study Limitations/Implications: It is required to standardize the method for it to be inexpensive.

Findings/Conclusions: The sexuality of papaya plants can be differentiated until the stage of flowering, which is why the implementation of molecular markers would facilitate plant selection if it is implemented at a large scale. Costs, maintenance time and elimination of plants of unwanted sex are reduced this way.

Keywords: Carica papaya, plant-sex, SCAR, in vitro plants.

\section{INTRODUCTION \\ Mexico}

exported 131,391 tons of papaya (Carica papaya L.) in 2014, with a value of 87 million dollars, and it was ranked as the top global exporter of this fruit. The volume increased $14 \%$ and the sales escalated $30.4 \%$ to inter-annual rates, marking a record in the value (SAGARPA, 2017).

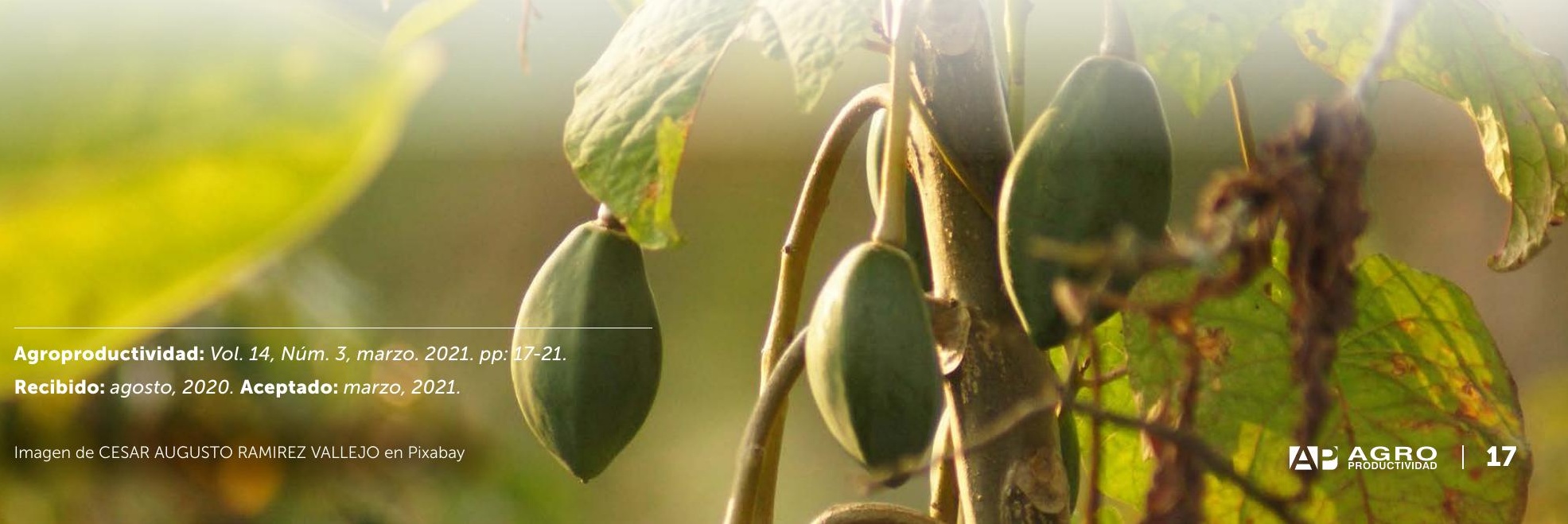


Papaya is a plant with dicotyledonous and polygamous diploid characteristics (Liu et al., 2004) (Caricaceae) (Badillo, 2002). Papaya cultivation presented considerable phenotypical variations with horticultural traits of great importance, which include physical and chemical characteristics such as size, shape, color, sugar content that influence its flavor (Kim et al., 2002; Oliveira et al., 2007). According to Ming et al. (2001), papaya is an excellent model for genomic and genetic research, which allows the possibility for genetic transformation, efficiency in breeding, high production of offspring, and continuous flowering.

The MSXJ papaya hybrid was developed by the National Institute of Forestry, Agriculture and Livestock Research (Instituto Nacional de Investigaciones Forestales, Agrícolas y Pecuarias, INIFAP) and it represents an alternative since one of its most outstanding characteristics is its tolerance to heat; it does not present abscission of flowers and fruits, and produces elongated fruits without deformations even when the environmental temperature exceeds $35{ }^{\circ} \mathrm{C}$ (Mirafuentes and Santamaría, 2014). However, the visual determination of sex in papaya plants in the vegetative state is not possible, since there are no embryological or morphological differences between the three sexual types. Therefore, sex determination is not carried out until flowering, which takes place four to six months after sowing. Therefore, sex determination has become a limitation for papaya growers since it implies higher costs and difficulties in planning the cultivation, especially in plantations where only hermaphrodite plants are required, since the best fruits are obtained from them (Hueso, 2015). Therefore, identifying the plant sex before flowering prevents additional costs and, because of this, sex identification before flowering through molecular markers represents an advantage.

The implementation of SCAR (Sequence Characterized Amplified Region) molecular markers (Parasnis et al., 2000; Deputy et al., 2002; Urasaki et al., 2002; ChavesBedoya and Núñez, 2007) allows discriminating the sex in papaya plants and therefore can be used in its prompt determination. The importance of the use of tools from molecular biology for sex identification before flowering, specifically the SCAR molecular markers that use specific primers developed from mapped or characterized sequences from other markers, has allowed sex identification in papaya plants (Deputy et al., 2002; Aspetia et al., 2014). These authors have used specific indicators such as T1, T12 and W11. Deputy et al. (2002) found that $\mathrm{T} 1$ serves as positive control, since it amplifies for female, male and hermaphrodite plants; T12 and W11 synthesize products for hermaphrodite and male plants, rarely for female plants. Aspetia et al. (2014) tested three sets of primers for SCAR markers: T1, T12 and W11. SCAR T1 generated bands of $800 \mathrm{pb}$ for hermaphrodite plants; T12 and W11 amplified $100 \%$ of hermaphrodite plants and null in feminine plants. The objective was to differentiate the sex of in vitro plants of the papaya (Carica papaya L.) MSXJ hybrid obtained via somatic organogenesis, through SCAR type molecular markers.

\section{MATERIALS AND METHODS}

This study began in the year 2016 and included two stages: 1) Development of seedlings of the MSXJ papaya hybrid using in vitro culture of apical meristems, via organogenesis and 2) Differentiation of the sex of in vitro plants through SCAR molecular markers.

The establishment of the in vitro culture of MSXJ papaya hybrid was carried out in the Agricultural Biotechnology Laboratory, of the company Agriculture and Livestock Genetic Production (Producción Genética Agropecuaria de México, PROGAMEX) located in the Innovation and Development Park of the state of Veracruz (Parque de Innovación y Desarrollo, PIDEV) in the Technological Institute and Superior Studies of Monterrey. The molecular studies were carried out in the Plant Biotechnology and Cryobiology LADISER of the Chemical Sciences School of the Universidad Veracruzana.

Explants from 20 plants of the MSXJ papaya hybrid were obtained in a plantation of the municipality of Cotaxtla, Veracruz, Mexico. The MST genotype (selection of Maradol cultivar) was used as masculine parent and $\mathrm{J}$ (landrace genotype) as female plants; the simple cross of these parents produced the MSXJ hybrid (Santamaría et al., 2013). The material used was collected when they were eight months of age in the stage of fructification.

\section{Sterile Establishment}

The explants were washed with abundant running water, later antibacterial soap was added, and they were placed in an orbital agitator (Ika ${ }^{\circledR}$-Werke GmbH\&Co.KG) during $30 \mathrm{~min}$ at $142 \mathrm{rpm}$, transferred into crystal containers with capacity for $250 \mathrm{~mL}$ and alcohol at $70 \%$ was added to the laminar flow bell for one minute; later they were submerged in a solution of commercial chlorine at 30\% during 30 min and they were washed three times with 
sterile distilled water to eliminate the remainders of chlorine.

\section{Extraction of the Apical Meristems}

For the extractions of meristems, a stereographic microscope was used (DIGITAL MICROSCOPE) of $12 \mathrm{VDC} 4 \mathrm{~A}$ max. $12 \mathrm{~V} / 15 \mathrm{~W}$ of transmitted light of $12 \mathrm{~V} / 10 \mathrm{~W}$. The leaf primordia were eliminated until leaving the meristems exposed, and then a cut was made on the base of the meristem. The meristems were placed in test tubes with $20 \mathrm{~mL}$ of the Murashige and Skoog basal medium (1962) at 100\% supplemented with $100 \mathrm{mg} \mathrm{L}^{-1}$ of Mio-Inositol, $0.4 \mathrm{mg} \mathrm{L}^{-1}$ of thiamine, $30 \mathrm{~g} \mathrm{~L}^{-1}$ of sucrose and $2.5 \mathrm{~g} \mathrm{~L}^{-1}$, phytagel at $\mathrm{pH} 5.7 \pm 0.01$, with a light period of $16 \mathrm{~h}$. A subculture was carried out after one month of sowing the meristems. The meristems were transferred to $250 \mathrm{~mL}^{-1}$ containers with $20 \mathrm{~mL}^{-1}$ in MS basal medium at $100 \%$ supplemented with $0.5 \mathrm{mg} \mathrm{L}^{-1}$ of BAP, $0.5 \mathrm{mg} \mathrm{L}^{-1}$ of AIA, $10 \mathrm{mg} \mathrm{L}^{-1}$ of adenine, $50 \mathrm{mg} \mathrm{L}^{-1}$ ascorbic acid and $100 \mathrm{mg} \mathrm{L}^{-1}$ citric acid, $40 \mathrm{mg} \mathrm{L}^{-1}$ of thiamine, $100 \mathrm{mg} \mathrm{L}^{-1}$ de Mio-Inositol and $30 \mathrm{~g} \mathrm{~L}^{-1}$ sucrose, phytagel $3 \mathrm{~g} \mathrm{~L}^{-1}, \mathrm{pH}$ 5.7 \pm 0.01 , with a photoperiod of $16 \mathrm{~h}$ light.

\section{DNA Amplification and Visualization}

For the extraction of DNA, $1 \mathrm{~cm}^{2}$ of leaf lamina was selected and the CTAB method was followed (cetyltrimethylammonium bromide) (Doyle and Doyle, 1990). The amplification reaction from PCR of DNA extracted from in vitro plants of the MSXJ papaya hybrid was made according to the protocol described by Deputy et al. (2002). Three primers were used: T1, T12 and W11 (Table 1).

The amplification of DNA from in vitro plants of MSXJ papaya hybrid was carried out in volumes of $25 \mu \mathrm{L}$ that contained $10 \mathrm{ng} \mu \mathrm{L}^{-1}$ of DNA, $2.5 \mathrm{u}$ of Taq\&GO (Mastermix 5xC, $M P^{\circledR}$ ),
Table 1. Sequence of SCAR primers used for the identification of sex in vitro plants of the papaya hybrid MSXJ.

\section{Primer}

Sequence

\begin{tabular}{c|l} 
T1-F & 5'-TGCTCT12-R TTGATATGCTCTCTG-3' \\
\hline T1-R & 5'-TACCTTCGCTCACCTCTGCA-3' \\
\hline T12-F & 5'-GGGTGTGTAGGCACTCTCCTT-3' \\
\hline T12-R & 5'-GGGTGTGTAGCATGCATGATA-3' \\
\hline W11-F & 5'-CTGATGCGTGTGTGGCTCTA-3 \\
\hline W11-R & 5'-CTGATGCGTGATCATCTACT-3' \\
\hline
\end{tabular}

period at $72{ }^{\circ} \mathrm{C}$ for $7 \mathrm{~min}$. The products from the amplification reaction were visualized in agarose gels at $1.5 \%$ supplemented with $1 \mu \mathrm{L}$ of ethidium bromide (10 $\mathrm{mg} \mathrm{mL}^{-1}$ ), the electrophoresis was carried out at $80 \mathrm{~V}$ during $1.5 \mathrm{~h}$, and the bands were observed with UV light in a transilluminator brand UVP PHOTODOC- ${ }^{\circledR}$ it I maging system.

It was used as a marker of molecular weight $1 \mathrm{~kb}$, sex identification was verified according to the number of pairs of bases. To identify hermaphrodite and feminine plants the T12 and W11 primers were used, which according to Aspetia et al. (2014) amplify for hermaphrodite plants, mark null for female plants, and with a double band of 800 pb and 1300 pb for male plants. T1 was used as positive control. To verify the association between markers and sex, a squared-Chi test was used.

\section{RESULTS AND DISCUSSION Sex Identification}

Figure 1 shows the case of the T12 primer, observing amplification in 12 hermaphrodite plants (Figure 1a) and eight female plants (Figure 1b), which agrees with Aspetia et al. (2014) who obtained amplification.

The W11 primer also amplified for hermaphrodite plants. These results agree with Saalau et al. (2009), who used a multiple methodology with the T1 and W11 primers, and they obtained a double band of 800 pb (for T1) and 1300 pb (for W11) for hermaphrodite plants.

The T1 primer was used as positive control, since according to Aspeitia et al. (2014), Saalau et al. (2009), and Deputy et al. (2002), it amplifies for the three sexes in papaya. In this study, although there were three samples that did not amplify for this primer, according to the 5X Buffer Reaction of $25 \mathrm{mM}$ ( $\mathrm{MgCl}_{2} 25 \mathrm{mM}$ ), dNTPs (1.25 mM each), $2.2 \mu \mathrm{L}$ of primer $\mathrm{R}$ and $2.2 \mu \mathrm{L}$ of primer $\mathrm{F}$, both at a final concentration of $2 \mu \mathrm{M}$.

The amplification was carried out in a Thermocycler brand NYXTECHNIK with an initial cycle at $95^{\circ} \mathrm{C}$ for 5 min, followed by 25 cycles at $95^{\circ} \mathrm{C}$ for one minute, 58 ${ }^{\circ} \mathrm{C}$ for one minute, $72{ }^{\circ} \mathrm{C}$ for $2 \mathrm{~min}$, and final extension
$\mathrm{Chi}^{2}$ test it can be considered as positive control with $99 \%$ of probability for sex determination in the MSXJ papaya hybrid, which agrees with the authors cited.

With the T1 primer, $80 \%$ of hermaphrodite plants were observed. The T1 primer had amplification of 1300 in a female plant and 800 for hermaphrodite plants. This does not agree with Sánchez and Núñez (2008), 

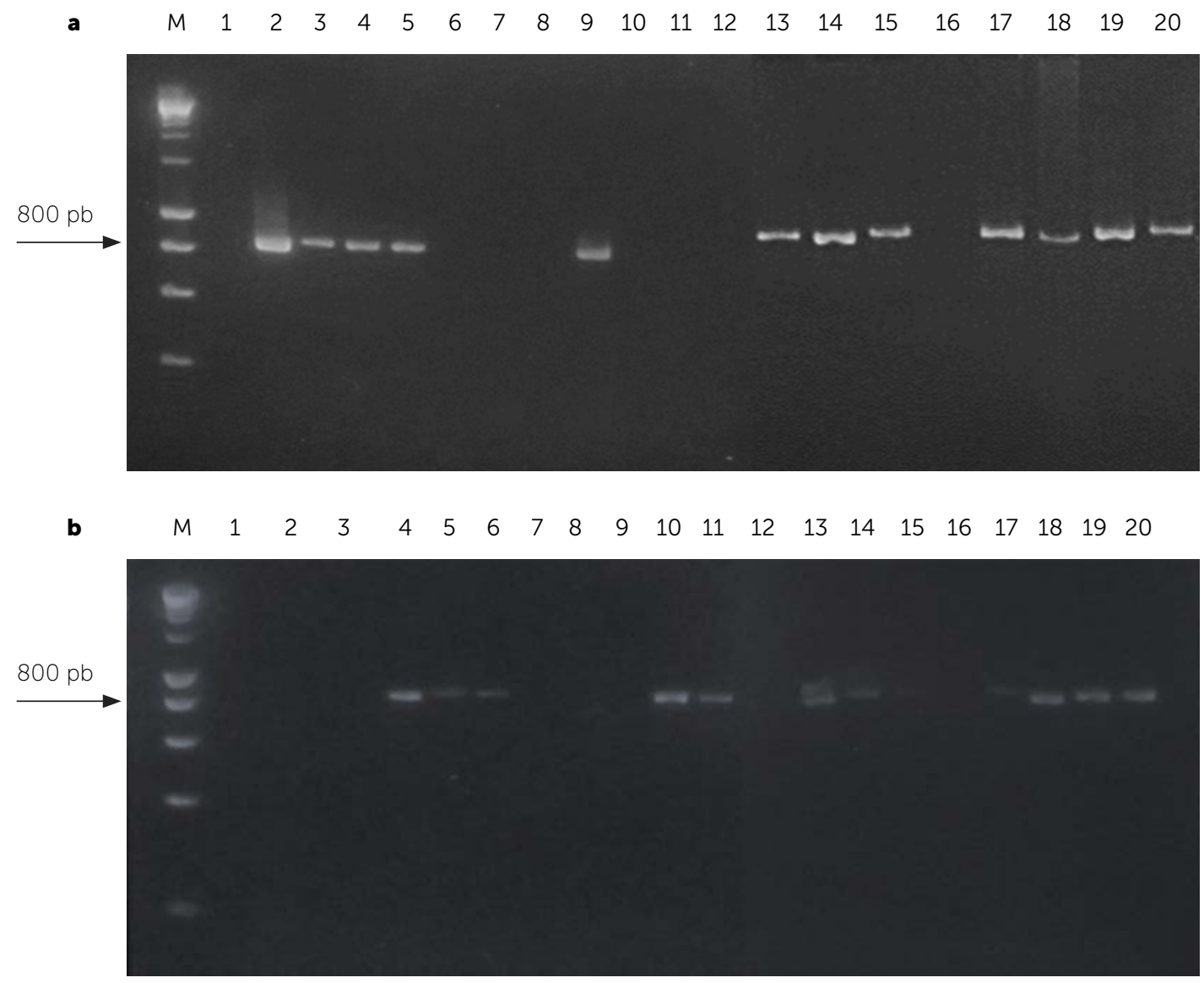

Figure 1. 1a. PCR products of DNA extracted and amplified using SCAR T12 as a primer for sex identification. Bands show hermaphroditic plants, absence indicates female papaya hybrid MSXJ plants. 1b. PCR products amplified from DNA using SCAR W11 as a primer for sex identification in the MSXJ papaya hybrid. The bands show hermaphroditic plants, while their absence indicates female plants.

which obtained bands of 1300 for hermaphrodite and masculine plants in Colombian papaya cultivars.

When performing the $\mathrm{Chi}^{2}$ test to compare the results obtained with the T12 primer to identify hermaphrodite plants and $\mathrm{T} 1$ as positive control no significant difference was found. Therefore, it is considered that this indicator is reliable, although according to Aspeitia et al. (2014) it is necessary to carry out more tests to verify the results. The results also agree with these authors', who obtained bands of $800 \mathrm{pb}$ for hermaphrodites and 1300 $\mathrm{pb}$ for females. With the W11 primer, they amplified hermaphrodite plants with fragments of 800 pb (Figure 1). Although some inconsistencies were observed, the $\mathrm{Chi}^{2}$ test was used to compare the results obtained with this primer and those obtained with the T1 and T12 primers were not significant.

\section{CONCLUSIONS}

The primers used (T1, T12 and W11) amplified bands of $800 \mathrm{pb}$ and $1300 \mathrm{pb}$ for hermaphrodites and null for females, with specificity for MSXJ hybrid papaya plants. Therefore, they can be used to implement a protocol for sex identification.

\section{AKNOWLEDGEMENTS}

The authors thank the National Council for Science and Technology for the support for a Master's studies scholarship in Ornamental Horticulture of the Universidad Veracruzana and the Agricultural Biotechnology Laboratory PROGAMEX (Agriculture and Livestock Production Genetics) for the plant material and the support provided to carry out this study.

\section{REFERENCES}

Aspeitia, V., Torres, M., Mendoza, D., \& Reyes, H. (2014). Evaluación de marcadores genéticos para la discriminación ente hembras y hermafroditas de papaya (Carica papaya L.) variedad Maradol. Revista Fitotecnia Mexicana 37: 193-197.

Badillo, V. M. (2002). Carica L. vs. Vasconcella St. Hil. (Caricaceae) con la rehabilitación de este último. Ernstia 10: 74-79.

Chaves-Bedoya, G., \& Núñez, V. (2007). A SCAR marker for the sex types determination in Colombian genotypes of Carica papaya. Euphytica 153: 215-220.

Deputy, J., Ming, R., Liu, M., Fitch, W., Wang, J., Manssardt, R., \& Stiles, J. (2002). Molecular markers for sex determination in papaya (Carica papaya L.). Theoretical and Applied Genetics 106: 107-111.

Doyle, J., J, \& Doyle. 1990. Isolation of plant DNA from fresh tissue. Focus 12: 13-15

Hueso, J., Salinas, I., \& Cuevas, J. 2015. El cultivo de Papaya. Fichas de Transferencia 009, p.1. Universidad Almería. España. 
Kim, M. S., Moore, P. H., Zee, F., Fitch, M. M., Steiger, D. L., Manshardt, R. M., Paull, R. E., Drew, R. A., Sekioka, T., \& Ming, R. (2002). Genetic diversity of Carica papaya as revealed by AFLP markers. Genome 45: 503-512.

Liu, Z., Moore, P., Ma, H., Ackerman, M., Ragilba, M., Yu, Q., Pearl, H., Kim, M., Charlton, J., Stiles, J., Zee, F., Paterson, A., \& Ming, R. (2004). A primitive Y chromosome in papaya marks incipient sex chromosome evolution. Nature 427: 348-352.

Ming, R., Moore, P. H., Zee, F., Abbey, C. A., Ma, H., \& Paterson, A. H. (2001). Construction and characterization of a papaya BAC library as a foundation for molecular dissection of a tree-fruit genome. Theor. Appl. Genet. 102, 892-899.

Mirafuentes, F., \& Santamaría, F. 2014. MSXJ, híbrido de papaya sin carpeloidía para el sureste de México. Revista Mexicana de Ciencias Agrícolas, abril-mayo, 1297-1301.

Murashige, T., \& Skoog, F. 1962. A revised medium for rapid growth and bioassays with tobacco tissue culture. Physiology plantarum 15: 473-497.

Oliveira, E., Loyola, J., Silva, M., Souza, D., Souza, H., \& Nunues, T. (2007). Marcadores moleculares na predição do sexo em plantas de mamoeiro. Pes. Agropec. Bras. 42(12), 1747-1754.

Parasnis, A. S., Ramakrishna, W., Chowdari, K. V., Gupta, V. S., \& Ranjekar, P. K. (1999). Microsatellite (GATA)n reveals sex-specific differences in papaya. Theor. Appl. Genet. 99: 1047-1052.

Santamaría, F., Mirafuentes, F., \& Rico, R 2014. MSXJ. Híbrido de papaya sin carpeloidía. Instituto Nacional de Investigaciones Forestales, Agrícolas y Pecuarias. Centro de Investigación Regional Sureste. Folleto técnico número 17. Mérida Yucatán, México $30 \mathrm{p}$.

SAGARPA., 2017. Secretaria de Agricultura, Ganadería, Desarrollo Rural Pesca y Alimentación Consulta de indicadores de producción nacional, precios y márgenes de comercialización de papaya. sagarpa.gob. mx

Solís, R., Olvera, J., R, \& La Rosa L. 2012. Propagación in vitro de Carica papaya var. PTM a partir de meristemos apicales. Revista Perú de Biología 18(3): 343-347.

Saalau, E., Barrantes, W., Loría, C., Brenes, A., \& Gómez, L, 2009. Identificación mediante PCR del sexo de la papaya (Carica papaya L.), híbrido Pococí. Agronomía Mesoamericana 20: 311-317.

Sánchez-Betancourt E., \& Núñez, V, 2008 Evaluación de marcadores moleculares tipo SCAR para determinar sexo en plantas de papaya (Carica papaya L.). Revista Corpoica-Ciencia y Tecnología Agropecuaria 9. 31-36.

Urasaki, N., Tokumoto, M., Tarora, K., Ban, Y., Kayano, T., Tanaka, H., Oku, H., Chinen, I., \& Terauchi, R. (2002). A male and hermaphrodite specific RAPD marker for papaya (Carica papaya L.). Theor. Appl. Genet. 104: 281-285.

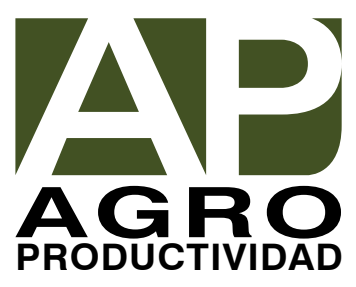

